\title{
Formulation and characterization of structural lightweight concrete containing residues of porcelain tile polishing, tire rubber and limestone
}

\author{
(Formulação e caracterização de concreto leve estrutural contendo \\ resíduos de polimento de porcelanato, borracha de pneus e calcário)
}

\author{
Z. L.M.Sampaio*, A. E. Martinelli, T.S. Gomes \\ Programa de Pós-graduação em Ciência e Engenharia de Materiais, \\ Universidade Federal do Rio Grande do Norte, Av. Salgado Filho 3000, Natal, RN 59072-970 \\ *zodinio@hotmail.com,martinelli.ufrn@gmail.com,tarc_sant@yahoo.com.br
}

\begin{abstract}
The recent increase in the construction industry has transformed concrete into an ideal choice to recycle a number of residues formerly discarded into the environment. Among various products, porcelain tile polishing, limestone and tire rubber residues are potential candidates to replace the fine aggregate of conventional mixtures. The aim of this study was to investigate the effect of the addition of varying contents of these residues in lightweight concrete where expanded clay replaced gravel. To that end, slump, compressive strength, density, void ratio, porosity and absorption tests were carried out. The densities of all concrete formulations studied were $10 \%$ lower to that of lightweight concrete $\left(<1.850 \mathrm{~kg} / \mathrm{m}^{3}\right)$. Nevertheless, mixes containing 10 to $15 \%$ of combined residues reduced absorption, void ratio and porosity, at least $17 \%$ lower compared to conventional concrete. The strength of such formulations reached $27 \mathrm{MPa}$ at 28 days with consistency of 9 to $12 \mathrm{~cm}$, indicating adequate consistency and increased strength. In addition, the combination of low porosity, absorption and voids suggested improved durability.

Keywords: lightweight concrete, porcelain tile polishing residue, tire rubber residue, limestone residue.
\end{abstract}

\section{Resumo}

\begin{abstract}
O recente aumento da indústria da construção civil transformou o concreto em uma escolha ideal para reciclar vários resíduos que anteriormente eram descartados no meio ambiente. Entre os vários produtos, os resíduos de polimento de porcelanato, calcário e borracha de pneus são candidatos potenciais para substituir agregados miúdos nas misturas convencionais. O objetivo deste estudo foi investigar o efeito da adição de diferentes teores desses resíduos no concreto leve, onde a argila expandida substituiu a brita. Para tal, foram realizados ensaios de abatimento, resistência à compressão, densidade, índice de vazios, porosidade e absorção. As densidades de todas as formulações de concreto estudadas foram $10 \%$ inferiores às do concreto leve $\left(<1,850 \mathrm{~kg} / \mathrm{m}^{3}\right)$. No entanto, misturas contendo 10 a 15\% de resíduos combinados representaram redução da absorção, índice de vazios e porosidade em pelo menos $17 \%$ em comparação com o concreto convencional. A resistência de tais formulações atingiu 27 MPa aos 28 dias com consistência de 9 a $12 \mathrm{~cm}$, indicando consistência adequada e aumento na resistência à compressão. Além disso, a combinação de baixa porosidade, absorção e vazios sugeriu maior durabilidade ao concreto.

Palavras-chave: concreto leve, resíduo de polimento de porcelanato, resíduo da borracha de pneu, resíduo de pedra calcária.
\end{abstract}

\section{INTRODUCTION}

In recent years, concrete has been one of the main forms of recycling of various residues that were once discarded into the environment [1-4]. The high energy demand involved in the construction industry [5] and the increasing consumption of concrete have pushed forward recycling initiatives of byproducts from various industries [6-10]. Aggregates account for 70 to $75 \%$ of the weight of concrete, resulting in an annual consumption of 7.5 billion tons. Thus, the use of residues to replace at least a fraction of the aggregates without major effects on the properties of concrete represents a significant improvement in the sustainability of the construction industry [11].

Porcelain tile is a ceramic that, as a function of its physical and chemical characteristics, has been used as an alternative to products such as granite and other natural stones. In the porcelain tile manufacturing process, more specifically in the polishing stage, large amounts of porcelain tile polishing residue (PPR) are generated [12]. PPR contains toxic metals from the manufacturing process, thus requiring managed disposal. Nevertheless, the high costs associated with the proper disposal of this waste have made this residue to be frequently discarded into the environment. This practice has caused great social and environmental concern, as Brazil is the world's second largest porcelain tile consumer and producer [13]. Studies have demonstrated the great application potential of PPR due to both its pozzolanic activity and the filler effect [14, 15]. Studies have also been carried out on residues such as 
limestone residue (LSR), from the mining and processing of rocks. They are usually discarded in lakes, rivers, roads and around mines. This practice becomes a serious environmental concern when the mines are located around the metropolitan areas [16]. Limestone mainly consists of calcite $\left(\mathrm{CaCO}_{3}\right)$ and is used by the construction industry as raw material in the manufacture of lime and cement. It is also used in agriculture as corrective agent for acid soils. LSR can reduce the use of natural aggregates (sand) in the production of concrete. However, literature on this topic is scarce.

Tire rubber residue (TRR) is another material that has undergone a considerable increase due to the worldwide increase in the vehicle fleet [17]. Approximately 1.5 billion tires are manufactured yearly worldwide [18]. TRR is usually disposed on landfills, however, due to its difficult decomposition and considerable reduction of the useful life of landfills with this practice, disposal has proved to be environmentally impracticable [6]. By 2030, roughly 5 billion tires will be discarded yearly without sustainable destination [19]. Several alternatives have already been studied in the construction industry to manage TRR, among which the production of asphalts, sports floors, road barriers, acoustic insulation panels and expansion joints [20]. Although the use of TRR as structural material is not feasible, since it considerably reduces the compressive strength of conventional concrete, researchers have shown great potential of TRR in other areas, especially in vibration damping, impact resistance, fire resistance, thermal insulation on facades, and others [8, 20, 21]. Lightweight concretes have gained wide acceptance in the construction market due to their numerous advantages over conventional concrete, including weight reduction, increase of useful area (due to reduced dimensions of structural parts), low handling costs and transport operations, increased thermal and acoustic insulation and fire resistance [22]. In the production of lightweight concretes, typically some or all the aggregates are replaced by lightweight aggregates including expanded clays, tire rubber residue, pumice, and expanded vermiculite among others, which considerably decreases the density of the material [9]. Concretes with density below $2000 \mathrm{~kg} / \mathrm{m}^{3}$ [23] are usually considered lightweight concretes, but ACI 213R-87 [24] defines density ranging from 1400 to $1850 \mathrm{~kg} / \mathrm{m}^{3}$.

The replacement of normal aggregates by low-density aggregates in the production of lightweight concrete decreases its compressive strength. The reduced concrete density while maintaining the strength of the material at acceptable levels without increasing the cement consumption (which increases the concrete production costs) is a real challenge. In this sense, the use of by-products to increase volume can be a viable option for the production of lowcost and sustainable lightweight concrete. Expanded clays are traditionally used to replace gravel (coarse aggregate), whereas residues of porcelain tile polishing, tire rubber and limestone can partially replace sand (fine aggregate). This study evaluated the effect of the addition of different residues (LSR, PPR and TRR) combined with expanded clay in the formulation of lightweight concretes. The resulting compositions were characterized by slump, compressive strength, density, void ratio, porosity and absorption tests.

\section{MATERIALS AND METHODS}

Portland cement, sand and expanded clay (EC1 and EC2) were used in the production of lightweight concrete. PC II 32 Z RS Portland cement from a single batch was used throughout the study. The fine aggregate used was clean river sand of coarse grain size $(4.8 \leq \mathrm{d} \leq 2.4 \mathrm{~mm})$. Two types of expanded clay were used, 1506 (EC1) and 0500 (EC2) as lightweight aggregate, replacing gravel. All residues used in this work (PPR - porcelain tile polishing residue, TRR - tire rubber residue, and LSR - limestone residue) originated from the local industries. TRR and LSR were used as-received in order to address the potential of such residues on large scale. Preliminary sieving was carried out with a $4.8 \mathrm{~mm}$ sieve to eliminate large particles and coarse impurities.

The mix design used was 1:0.83:0.875:0.375 (cement:sand:EC1:EC2, Table I). The water to cement ratio was 0.50 with the addition of $1 \%$ Glenium SKY 150 superplasticizer by the weight of cement to maintain proper concrete workability. PPR, TRR and LSR residues were added to this mix in different ratios (Table II). In the formulation of the different concrete mixes, a $2^{3}$ full factorial planning was used, with variables in the following levels: PPR 5-15\%, LSR 4-12\% and TRR 1-5\%. Altogether,

Table I - Composition of reference lightweight concrete mix $\left(\mathrm{kg} / \mathrm{m}^{3}\right)$.

[Tabela I - Composição da mistura de concreto leve de referência $\left(\mathrm{kg} / \mathrm{m}^{3}\right)$.]

\begin{tabular}{ccccc}
\hline Sample & Cement & Sand & EC0500 & EC1506 \\
\hline CP & 535.71 & 444.64 & 468.79 & 200.93 \\
\hline
\end{tabular}

Table II - Residues contents $\left(\mathrm{kg} / \mathrm{m}^{3}\right.$; fraction in relation to cement) added in the reference composition (CP).

[Tabela II - Teores de resíduos ( $\mathrm{kg} / \mathrm{m}^{3}$; fração em relação ao cimento) adicionados na composição de referência $(C P)$.]

\begin{tabular}{cccc}
\hline Sample & PPR & LSR & TRR \\
\hline T1 & $80.36(15 \%)$ & $64.29(12 \%)$ & $26.79(5 \%)$ \\
T2 & $53.57(10 \%)$ & $42.86(8 \%)$ & $16.07(3 \%)$ \\
T3 & $26.79(5 \%)$ & $21.43(4 \%)$ & $5.36(1 \%)$ \\
T4 & $80.36(15 \%)$ & $21.43(4 \%)$ & $5.36(1 \%)$ \\
T5 & $26.79(5 \%)$ & $64.29(12 \%)$ & $5.36(1 \%)$ \\
T6 & $80.36(15 \%)$ & $64.29(12 \%)$ & $5.36(1 \%)$ \\
T7 & $26.79(5 \%)$ & $21.43(4 \%)$ & $26.79(5 \%)$ \\
T8 & $80.36(15 \%)$ & $21.43(4 \%)$ & $26.79(5 \%)$ \\
T9 & $26.79(5 \%)$ & $64.29(12 \%)$ & $26.79(5 \%)$ \\
\hline
\end{tabular}


Table III - Selected characteristics of cement, aggregates and residues.

[Tabela III - Características selecionadas de cimento, agregados e resíduos.]

\begin{tabular}{cccccccc}
\hline Characteristic & EC0500 & EC1506 & PPR & LSR & TRR & Sand & Cement \\
\hline Maximum diameter $(\mathrm{mm})$ & 6.3 & 19.0 & - & 4.8 & 4.8 & 4.8 & - \\
Fineness modulus & 4.85 & 6.47 & 2.35 & 2.78 & 3.60 & 2.29 & 1.80 \\
Unit weight $\left(\mathrm{g} / \mathrm{cm}^{3}\right)$ & 0.64 & 0.51 & 1.25 & 1.55 & 0.65 & 1.46 & 1.42 \\
Density $\left(\mathrm{g} / \mathrm{cm}^{3}\right)$ & 1.23 & 0.93 & 2.60 & 2.62 & 0.95 & 2.63 & 3.01 \\
\hline
\end{tabular}

9 different concrete mixes were produced and labeled T1 to T9. Three samples were prepared for the central point of the statistical study in order to establish the experimental

Table IV - Absorption (\%) of expanded clays.

[Tabela IV - Absorção (\%) de argilas expandidas.]

\begin{tabular}{cccccc}
\hline Time $(\mathrm{min})$ & 15 & 30 & 45 & 60 & 1 day \\
\hline EC 0500 & 6.95 & 9.45 & 10.99 & 11.05 & 15.30 \\
EC 1506 & 5.72 & 8.00 & 9.24 & 9.46 & 13.50 \\
\hline
\end{tabular}

Table V - Compressive strength and expansibility of Portland cement.

[Tabela V - Resistência à compressão e expansibilidade do cimento Portland.]

\begin{tabular}{cccc}
\hline Time (day) & 3 & 7 & 28 \\
\hline Compressive strength (MPa) & 22.57 & 29.15 & 37.92 \\
Expansibility (mm) & - & 2 & - \\
\hline
\end{tabular}

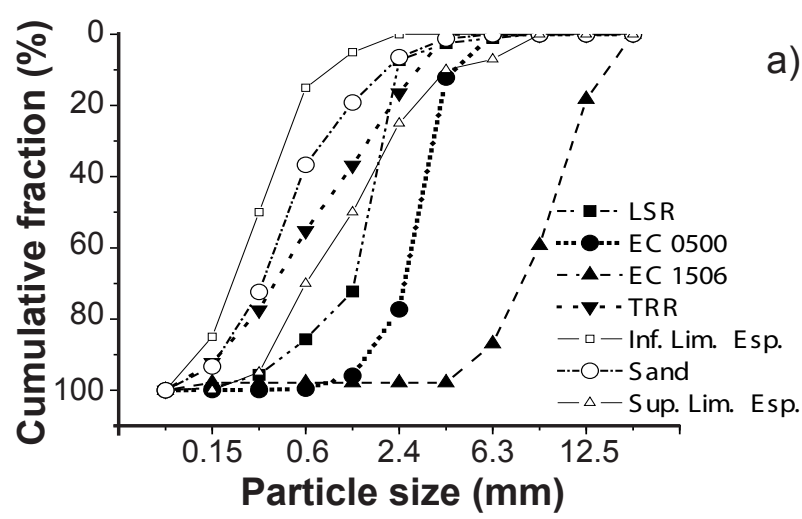

error. For each mix, different PPR (5, 10 and 15\%), LSR (4, 8 and $12 \%)$ and TRR (1,3 and 5\%) contents were added. A reference lightweight composition (CP) was also prepared for comparison purposes.

The cement fineness index was obtained from the material retained in the $75 \mu \mathrm{m}$ sieve. Cement compressive strength tests were performed using $5 \mathrm{~cm}$ (diameter) $\times 10 \mathrm{~cm}$ (height) cylindrical mortar specimens according to current standards. The real density of the cement was determined by the Le Chatelier test, whereas expansion was measured at 7 days using a Le Chatelier needle. The Vicat apparatus was used to establish the cement setting time. All aggregates (sand, PPR, TRR, LSR and EC) underwent density, unit mass and particle size distribution tests. For the density tests, the Chapman flask was used. The unit mass tests were performed using a $13 \mathrm{~L}$ cubic box. Particle size distributions were determined using a set of sieves $(4.8,2.4,1.2,0.6,0.3$ and $0.15 \mathrm{~mm})$ and a mechanical stirrer. Selected characteristics of the materials used in the formulation of lightweight concrete are listed in Tables III to V, whereas particle size distributions are

Figure 1: Particle size distribution curves of (a) residues and aggregates and (b) PPR.

[Figura 1: Curvas de distribuição do tamanho de partícula de (a) resíduos e agregados e (b) PPR.]

Table VI - Chemical composition of residues by XRF.

[Tabela VI - Composição química por FRX dos resíduos.]

\begin{tabular}{ccccccccccc}
\hline Oxide & $\mathrm{SiO}_{2}$ & $\mathrm{Fe}_{2} \mathrm{O}_{3}$ & $\mathrm{Al}_{2} \mathrm{O}_{3}$ & $\mathrm{~K}_{2} \mathrm{O}$ & $\mathrm{MgO}$ & $\mathrm{TiO}_{2}$ & $\mathrm{CaO}$ & $\mathrm{MnO}$ & $\mathrm{ZrO}_{2}$ & $\mathrm{Na}_{2} \mathrm{O}$ \\
\hline EC0500 & 45.89 & 25.33 & 18.13 & 5.28 & 3.04 & 1.40 & 0.71 & 0.22 & - & - \\
EC1506 & 46.21 & 24.56 & 18.24 & 5.19 & 2.94 & 1.35 & 0.62 & 0.20 & 0.69 & - \\
LSR & 8.92 & 7.35 & 4.08 & 1.34 & 0.98 & - & 76.64 & 0.15 & 0.51 & - \\
PPR & 71.68 & 1.09 & 18.99 & 3.85 & 1.40 & 0.20 & - & 0.04 & 0.61 & 1.90 \\
\hline
\end{tabular}



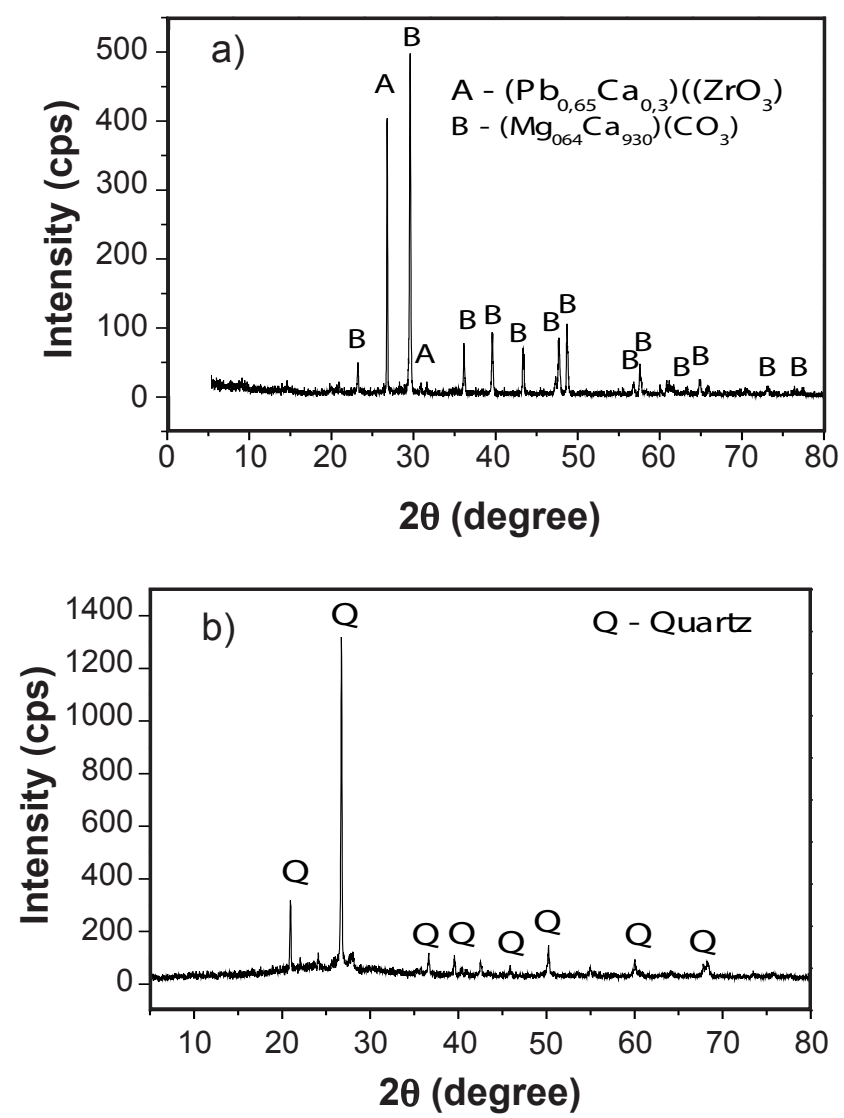

Figure 2: X-ray diffraction patterns of (a) LSR and (b) PPR. [Figura 2: Difratogramas de raios X de (a) LSR e (b) PPR.]

illustrated in Fig. 1. The chemical characterization of PPR, LSR, EC1 and EC2 aggregates was carried out by X-ray fluorescence (XRF) and X-ray diffraction (XRD), and the results are shown in Table VI and Fig. 2, respectively.

Slump tests were carried out only for fresh concrete. To perform the tests, 12 cylindrical specimens of $10 \mathrm{~cm}$ (diameter) x $20 \mathrm{~cm}$ (height) were prepared for each of the ten mixes studied. After $24 \mathrm{~h}$ at rest, samples were demolded and subjected to immersion cure during 7 and 28 days. After curing, immersion absorption, voids, porosity and density tests took place for each mix using the mass of specimens in the dry, saturated and submerged state. Compressive strength tests in the cylindrical specimens were performed at 7 and 28 days.

\section{RESULTS AND DISCUSSION}

LSR (limestone residue) consisted predominantly of $\mathrm{CaO}$ $(\sim 76 \%)$ in addition to $\mathrm{Al}_{2} \mathrm{O}_{3}, \mathrm{SiO}_{2}$ and $\mathrm{Fe}_{2} \mathrm{O}_{3}$. PPR (porcelain tile polishing residue) presented as main compounds $\mathrm{SiO}_{2}$ (71.68\%) and $\mathrm{Al}_{2} \mathrm{O}_{3}$ (18.99\%). The chemical analysis also showed very low levels of $\mathrm{MgO}, \mathrm{K}_{2} \mathrm{O}, \mathrm{ZrO}_{2}$ and $\mathrm{MnO}$ for both residues. EC1 and EC2 clays, as expected, consisted mainly of silicates, aluminates, ferrites and some impurities in the form of $\mathrm{K}_{2} \mathrm{O}, \mathrm{MgO}, \mathrm{TiO}_{2}, \mathrm{CaO}$ and $\mathrm{MnO}$ (Table VI). Analysis by XRD (Fig. 2b) showed that PPR was an amorphous material with some crystalline quartz.
Amorphous materials typically have high reactivity with the cement calcium hydroxide (pozzolanic reaction), thereby increasing the compressive strength of hardened material.

Results from slump test showed that the consistency of concrete with residues (LCR) decreased for high PPR and/ or LSR contents (Fig. 3). Very fine aggregates absorb water, thus reducing the total amount of water required to maintain consistency, which consequently makes the concrete less plastic. This explains why the slump results were lower than those obtained elsewhere [25,26]. Moreover, concretes with medium to low contents of residues (T2, T9, T3 and T7) presented far better consistency when compared to concrete with high PPR and LSR levels (T1, T4, T5, T6 and T8). Concrete T7 showed consistency about $83 \%$ better than all other LCRs. The maximum TRR level (5\%) used in the production of this concrete and the low amount of PPR (5\%) and LSR (4\%) significantly contributed to maintain consistency at least $25 \%$ higher than that of the other LCR and obtained in [27].

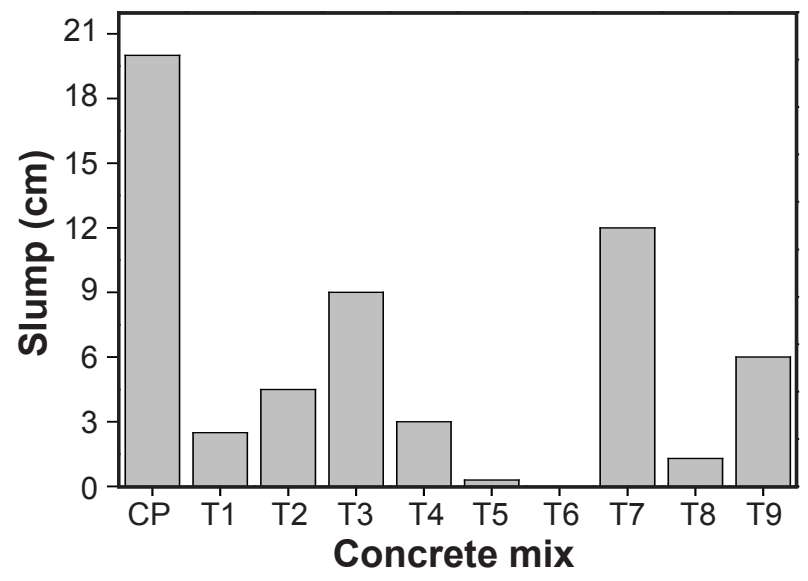

Figure 3: Results of slump test.

[Figura 3: Resultados de abatimento.]

Porosity, absorption and void ratio are properties related to concrete durability. Concretes with low void ratio, absorption and porosity are more compact and waterproof and tend keep service properties for longer times. The results in Fig. 4 show a reduction in the void ratio, porosity and absorption of at least $17 \%$ of all LCRs in relation to PC concrete. Concretes T2, T5 and T6 showed reduction of almost $40 \%$ in porosity in relation to PC and almost $50 \%$ when compared with concretes made in [28]. This behavior can be explained by the filler effect and pozzolanic reaction of PPR with calcium hydroxide $(\mathrm{CH})$. The particle size results in Fig. 1 showed large amounts of fine particles that acted in the filling of concrete micropores, which characterized the filler effect. The high amount of silica in the amorphous state of PPR observed by XRD and XRF results support the pozzolanic reaction. The combination of the filler effect and the pozzolanic reaction resulted in less porous and more impermeable concrete. This fact resulted in decreased void ratio, porosity and absorption provided by LCR T2, T5 and T6. The values obtained for the previously 
mentioned properties were similar to those found in the literature for lightweight concretes [25, 29].

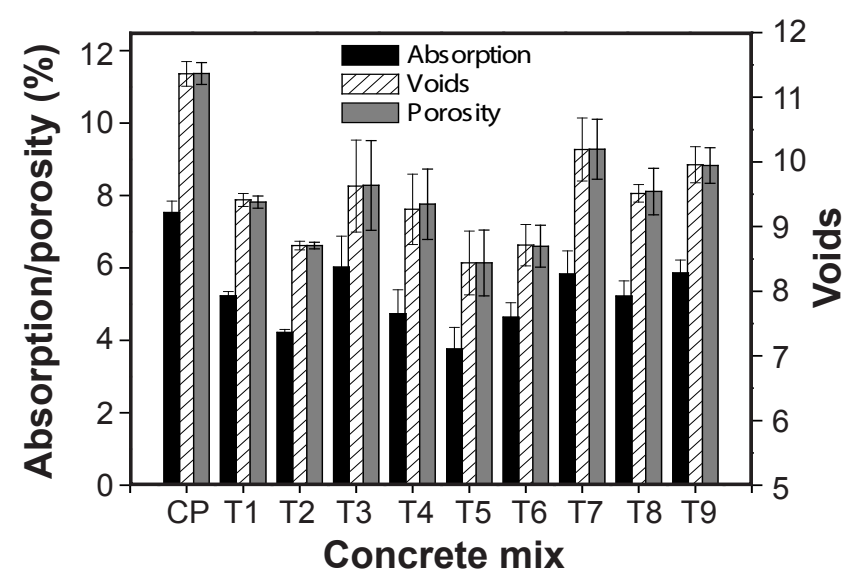

Figure 4: Results of absorption, porosity and voids.

[Figura 4: Resultados de absorção, porosidade e vazios.]

There was no significant variation in density with different sources of residues (Fig. 5). All concrete samples produced had density less than $1700 \mathrm{~kg} / \mathrm{m}^{3}$. This value is $10 \%$ lower than reported elsewhere $[25,27,28]$ and $1850 \mathrm{~kg} / \mathrm{m}^{3}$, which is the density that ACI 213-87R [24] recommends for lightweight concrete, and at least $20 \%$ lower than those reported for lightweight concrete $[26,30]$. The low density of concretes is due to the replacement of normal coarse aggregates of density around $2600 \mathrm{~kg} / \mathrm{m}^{3}$ by EC0500 and EC1506 with densities of 1230 and $930 \mathrm{~kg} / \mathrm{m}^{3}$, respectively.

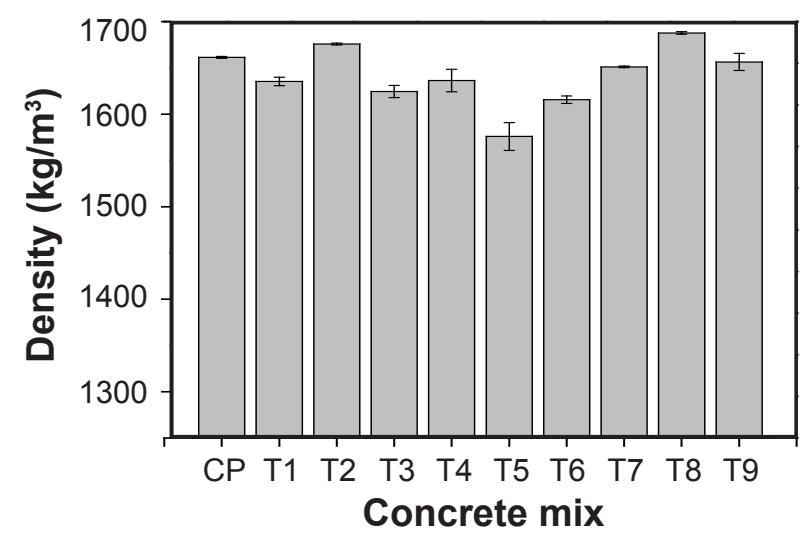

Figure 5: Density of lightweight concrete mixes.

[Figura 5: Densidade de misturas de concretos leves.]

The results illustrated in Fig. 6 show that the strength at 28 days of all concretes containing residues exceeded that of PC formulation by at least $3 \%$. These results are similar to those reported in the literature $[25,30]$ and almost $50 \%$ greater than that obtained in [28]. The strength of LCR T5 and T6 at 28 days exceeded all others by at least $20 \%$. This increase was probably caused by the low percentage of TRR present. Absorption, porosity and void ratio significantly contributed to the concrete strength. Waterproof and denser concretes tend to have higher strengths. The gain in strength can be explained by both the filler and pozzolanic effects. The reduced strength of $\mathrm{T} 1$ compared to the others may have been caused by the high contents of residues present (PPR 15\%, LSR $12 \%$ and TRR 5\%). A relatively slow strength gain of T7 was observed, which showed strength at 7 days nearly $18 \%$ less than PC. It is possible that the high TRR content (5\%) combined with low PPR and LSR levels (5 and $4 \%$, respectively) have contributed to decrease the strength gain at early ages.

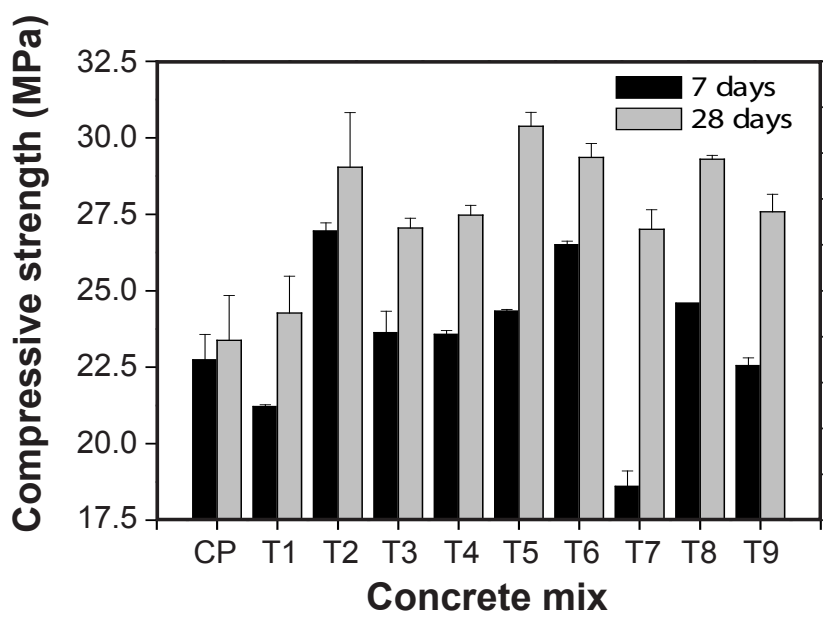

Figure 6: Compressive strength at 7 and 28 days. [Figura 6: Resistência à compressão aos 7 e 28 dias.]

Fig. 7 shows that the best results were obtained for LCR $\mathrm{T} 3$ and T7. These concrete samples showed strength in the order of $27 \mathrm{MPa}$ at 28 days with consistency of 9-12 cm. Although T5 and T6 have shown better performance in terms of strength, they showed low slump. Consistency is related to the mix fluidity (plasticity degree) and the aspects that most affect this property are the water to dry materials ratio and the characteristics of aggregates such as shape and surface finishing of the particles. PPR and LSR tend to absorb more water due to the large amount of fine particles shown

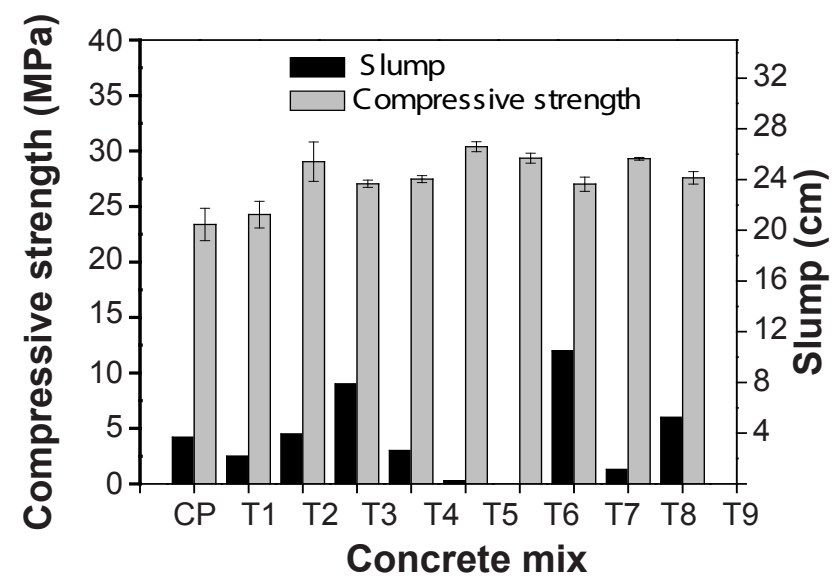

Figure 7: Comparative plot of compressive strength and slump of lightweight concrete mixes.

[Figura 7: Gráfico comparativo da resistência à compressão e abatimento de misturas de concretos leves.] 
in the grain size distributions (Fig. 1). The water absorption by these aggregates decreases the amount of water required to maintain consistency, thus making the material drier. LCR T7 showed better consistency due to its low content of PPR (5\%), LSR (4\%) and also to the higher amount of rubber $(5 \%)$. The shape of TRR and surface finishing contribute to the improvement of consistency.

\section{CONCLUSIONS}

No significant differences in density were observed among the different LCR formulations in the concentration range of PPR (porcelain tile polishing residue), LSR (limestone residue) and TRR (tire rubber residue) studied. Formulations with low PPR and LSR levels (5 to $10 \%$ and 4 to $8 \%$, respectively) and high TRR levels (3 to 5\%) showed higher consistencies. Contents from 3 to $5 \%$ of rubber reduced the compressive strength and increased consistency. The addition of PPR and LSR improved compactness and compression strength of all LCRs, reducing absorption, void ratio and porosity. The use of PPR, LSR and TRR probably improve durability related properties, since a significant reduction in deleterious characteristics to concrete permeability were observed along with an improvement in compression strength. The use of these by-products in concretes can allow numerous technical and economic advantages since they improve some concrete properties such as compressive strength, porosity and absorption. The addition of residues in concrete also can contribute to sustainability since it reduces the disposal of these products into the environment. The best overall results were obtained for LCR T3 (5\% PPR, 4\% LSR, 1\% TRR) and T7 (5\% PPR, $4 \%$ LSR, $5 \%$ TRR).

\section{ACKNOWLEDGEMENTS}

The authors would like to acknowledge CAPES-Brazil and PPGCEM-UFRN for the support granted to this work.

\section{REFERENCES}

[1] Z. Sampaio, P.A.B.F. Souza, B.G. Gouveia, Rev. Ibracon Struct. Mater. 7 (2014) 626.

[2] A. Al-Sibahy, R. Edwards, Constr. Build. Mater. 31 (2012) 157.

[3] A. Kılıç, C.D. Atiş, E. Yaşar, F. Özcan, Cem. Concr. Res. 33 (2003) 1595.

[4] P. Posi, S. Lertnimoolchai, V. Sata, P. Chindaprasirt, Constr. Build. Mater. 47 (2013) 896.

[5] M.Y.J. Liu, U.J. Alengaram, M.Z. Jumaat, K.H. Mo, Energy Build. 72 (2014) 238.

[6] W.H. Yung, L.C. Yung, L.H. Hua, Constr. Build. Mater. 41 (2013) 665.
[7] M. Thomas, T. Bremner, Cem. Concr. Res. 42 (2012) 358.

[8] H.-Y. Wang, B.-T. Chen, Y.-W. Wu, Constr. Build. Mater. 41 (2013) 526.

[9] P. Shafigh, H. Bin Mahmud, M.Z. Bin Jumaat, R. Ahmmad, S. Bahri, J. Clean. Prod. 80 (2014) 187.

[10] O. Sengul, S. Azizi, F. Karaosmanoglu, M.A. Tasdemir, Energy Build. 43 (2011) 671.

[11] A. Barbudo, J. de Brito, L. Evangelista, M. Bravo, F. Agrela, J. Clean. Prod. 15 (2013) 93.

[12] N.U. Kockal, T. Ozturan, Mater. Des. 32 (2011) 3586.

[13] Assoc. Ital. Manuf. Mach. Equip. Ceram., "World production and consumption of ceramic tiles" (2015), $<$ http://www.tiledizioni.it/>

[14] F. Andreola, L. Barbieri, I. Lancellotti, M.C. Bignozzi, F.Sandrolini, Int. J. Appl. Ceram. Technol. 7, 4 (2010) 546.

[15] F. Pelisser, L.R. Steiner, A.M. Bernardin, Env. Sci Technol. 46 (2012) 2368.

[16] A.J. Puppala, S. Saride, R. Williammee, J. Mater. Civ. Eng. 24 (2012) 418.

[17] B.S. Thomas, R.C. Gupta, J. Clean. Prod. 102 (2015) 78.

[18] F. Pelisser, A. Barcelos, D. Santos, M. Peterson, A.M. Bernardin, J. Clean. Prod. 23 (2012) 68.

[19] F. Azevedo, F. Pacheco-Torgal, C. Jesus, J.L. Barroso de Aguiar, A.F. Camões, Constr. Build. Mater. 34 (2012) 186.

[20] A.M. Marques, J.R. Correia, J. de Brito, Fire Saf. J. 58 (2013) 49.

[21] C.A. Issa, G. Salem, Constr. Build. Mater. 42 (2013) 48. [22] J.A. Bogas, J. de Brito, J.M. Figueiredo, J. Clean. Prod. 89 (2015) 187.

[23] J.B. Newman, in: Strutural lightweight aggregate concrete, J.L. Clarke (Ed.), Blackie Acad. Prof. (2005) 1023.

[24] Am. Concr. Inst., "Guide for structural lightweight aggregate concrete", ACI 213R-87 (1999).

[25] P. Shafigh, M.A. Nomeli, U.J. Alengaram, H.B. Mahmud, M.Z. Jumaat, J. Clean. Prod. 135 (2016) 148.

[26] J.J. Li, C.J. Wan, J.G. Niu, L.F. Wu, Y.C. Wu, Constr. Build. Mater. 131 (2017) 449.

[27] R. Ahmmad, M.Z. Jumaat, U.J. Alengaram, S. Bahri, M.A. Rehman, H. bin Hashim, J. Clean. Prod. 112, 1 (2016) 566.

[28] F. Colangelo, R. Cioffi, B. Liguori, F. Iucolano, Compos. Part B: Eng. 106 (2016) 234.

[29] K.H. Mo, U.J. Alengaram, M.Z. Jumaat, M.Y.J. Liu, J. Lim, J. Clean. Prod. 112, 1 (2016) 763.

[30] T. Gupta, S. Chaudhary, R.K. Sharma, "Assessment of mechanical and durability properties of concrete containing waste rubber tire as fine aggregate", Constr. Build. Mater. 73 (2014) 562.

(Rec. 26/08/2016, Rev. 29/12/2016, Ac. 08/04/2017) 